\title{
ЮРИДИКО-ПСИХОЛОГІЧНІ ТА МЕДИЧНІ АСПЕКТИ КОМУНІКАТИВНОЇ ГОТОВНОСТІ СЛІДЧОГО ПІД ЧАС ДОПИТУ
}

Пасько О. М., Нікітенко Р. П.

Авторами розглянуто комунікативну готовність слідчого під час доnumy. Від уміння вести бесіду із співрозмовником залежить подальше ставлення до слідчого. Особливості спілкування $\epsilon$ необхідними не тільки для встановлення психологічного контакту з асоціальною групою суспільства, але й для відносин із колегами, що дасть змогу своєчасно скоординувати професійні зусилля і попередити злочин.

Наголошується, що допит - че складна слідча дія, що зумовлена певними труднощами, з якими стикаються слідчі підрозділи органів Начіональної поліції, оскільки він пов'язаний із процесом встановлення психологічного контакту з учасниками кримінального провадження, за результатом проведення якого необхідно отримати важливу інформацію.

Визначено, що психологічними особливостями проведення допиту $\epsilon$ чітка регламентація, невизначеність плину комунікативного процесу, конфліктність, необхідність високого ступеня концентраціі слідчого на процесі допиту, необхідність грунтовної підготовки до проведення допиту, можливість зміни інформації, наявність недовіри до представників правоохоронних органів та небажання у зв'язку із цим давати правдиву інформацію, звертання уваги на обмовки та дрібниці, які можуть бути корисними для розслідування матеріалів кримінального провадження та ін.

Фізіологічною основою особистості $\epsilon$ mun вищої нервової діяльності людини, який відображає силу та динаміку нервових процесів у мозку. Специфіку психоемоційного стресу особи, до якої не завжди застосовуються закономірності процесу розвитку, $\epsilon$ ступінь прояву ознак стресу. I тут буде залежати від низки факторів та психічних станів (мотивація, установка, очікування). Якщо свідомість оцінує ситуацію як небезпечну, то відбувається емоційна оцінка подіï.

Важливим $\epsilon$ врахування фізіологічного та медичного аспектів під час спілкування слідчого з підозрюваним. Оскільки мозок знає правду і вербально може сказати недостовірну інформацію, невербальне тіло видає себе у зв'язку з фізіологічними процесами, які відбуваються в організмі на фоні дії гормонів адреналіну та кортизолу.

( ) Пасько О. М., Нікітенко Р. П., 2020
Ключові слова: комунікативна готовність, допит, вербальне спілкування, невербальне спілкування, адреналін, кортизол.

Pasko O. M., Nikitenko R. P. Legal-psychological and medical aspects of communication readiness of the investigator during interrogation

The article deals with the communication readiness of the investigator during interrogation. The skills of making conversation with a partner predispose the further attitude to the investigator. Peculiarities of communication are necessary not only to interrelate with antisocial elements, but also for good relationships with colleagues, which will allow to coordinate timely professional efforts and prevent crime.

The authors underline that interrogation is a complex investigative measure which is caused by certain difficulties faced by the investigative units of the National Police, as it is associated with the process of making psychological contact with the criminal proceedings participants, as a result of which important information must be obtained.

It is determined that the psychological features of the interrogation are as follows: clear regulation, uncertainty of the communicative process course, proneness to conflict, the need for a high degree of the investigator's fixation at the the interrogation, the need for thorough preparation for the interrogation making, the possibility of changing information, distrust of the law enforcement officials and as a result the reluctance to give truthful information, paying attention to reservations and trifles which can be useful for criminal case files investigation, etc.

The physiological basis of personality is the type of higher nervous activity of a man, which reflects the strength and dynamics of nerve processes in the brain. Psycho-emotional stress of a person manifests in different degree. This situation will depend on a number of factors and mental states (motivation, attitude, expectations). If the consciousness evaluates the situation as dangerous, emotional assessment of the event takes place.

It is important to take into account the physiological and medical aspects during communication of the investigator with a suspect. As the brain knows the truth and can verbally tell false information, the nonverbal body betrays itself due to physiological processes that take place in the body against a background of the hormones adrenaline and cortisol.

Key words: communication readiness, interrogation, verbal communication, nonverbal communication, adrenaline, cortisol. 
Постановка проблеми та іiі актуальність. Сучасний стан державотворення зумовлюється сукупністю змін у всіх сферах життєдіяльності, що суттєво впливає на рівень компетентності та спроможності працівників на найвищому рівні виконувати функціональні обов'язки. Професія слідчого належить до соціономічної сфери діяльності, $\epsilon$ різновидом групи професій «людина-людина» i, відповідно, зумовлюється постійним спілкуванням у виконанні професійної діяльності.

Саме тому слідчий органу досудового розслідування має володіти сукупністю знань, умінь та навичок щодо психологічних особливостей спілкування та застосувати комунікативні методи та прийоми з метою викриття неправдивих свідчень та встановлення істини по справі.

Перебуваючи в постійному комунікативному потоці, слідчий може бути спонукаючою основою для розкриття достовірних відомостей, відновлення справедливості та покарання правопорушника. Від уміння вести бесіду із співрозмовником залежить подальше відношення до слідчого. Особливості спілкування для слідчого $є$ необхідними не тільки для встановлення психологічного контакту з асоціальною групою суспільства, але й для відносин із колегами, що дасть змогу своєчасно скоординувати професійні зусилля і попередити злочин.

Аналіз останніх досліджень i публікацій. Питання комунікативних особливостей в особистій та професійній сферах висвітлювались у вітчизняних та зарубіжних вчених, зокрема: С.П. Архипова, С.А. Білоусова, В.Й. Бочелюка, Г.О. Горбаня, М. Гончарової-Горянської, С.Є. Корабльова, О.І. Мартинюка, І.Н. Медведєва, С.В. Панькова, О.І. Соловйова, О.І. Пометуна, Дж. Равена, В. Хутмахера, А.А. Ярулова та ін.

Особливості комунікативного потенціалу особистості, формування комунікативних здібностей та якостей розроблялись видатними науковцями (М.М. Бахтін, О.О. Бодальов, М.Й. Боришевський, O.В. Брушлінський, Л.П. Буєва, М.С. Каган, В.О. Кан-Калік, М.Н. Корнєв, Б.Ф. Ломов, О.О. Леонтьєв, С.Д. Максименко, В.П. Москалець, Л.Е. Орбан, Н.І. Пов'якель, С.В. Савчин, В.А. Семіченко, С.В. Терещук, Т.М. Титаренко, А.У. Хараш, Т.С. Яценко та ін.), а психологічні детермінанти підвищення комунікативного потенціалу слідчих висвітлювались відомими науковцями (В.Г. Андросюк, О.М. Бандурка, В.І. Барко, А.Ф. Зелінський, Л.І. Казміренко, М.В. Костицький, С.Д. Максименко, Т.М. Малкова, В.С. Медведєв, Л.І. Мороз, Г.В. Попова, В.М. Синьов, О.В. Тимченко, О.М. Цільмак, С.І. Яковенко та ін.).
У вітчизняних та зарубіжних роботах визначають комунікативну компетентність слідчого, проте, крім спроможності використовувати знання, вміння та навички, він має бути готовим їх реалізовувати.

Нагальними постає питання відповідності слідчим найвищому рівню професійної діяльності органів досудового розслідування. Для цього він має володіти комунікативною готовністю. У вітчизняних та зарубіжних роботах визначають комунікативну готовність слідчого, проте, крім спроможності використовувати знання, вміння та навички, він має бути готовим їх реалізовувати. Тому нами було розглянуто комунікативну готовність щодо проведення допиту слідчого крізь призму юридичного, психологічного та медичного аспектів.

Метою статті $\epsilon$ уніфікація особливостей невербального спілкування та ознаки брехні крізь призму юридичного, психологічного та медичного аспектів.

Відповідно до мети дослідження вирішувалися такі завдання:

1) розглянути сучасний стан наукової розробки комунікативної готовності слідчого під час допиту;

2) систематизувати та уніфікувати єдині характеристики ознаки брехні, які визначаються крізь призму юридичного, психологічного та медичного аспектів;

3) обґрунтувати необхідність та доцільність врахування особливостей невербальної комунікації під час встановлення істини з кримінального провадження.

Для вирішення поставлених завдань використано теоретичні взаємопов'язані методи дослідження: аналіз, порівняння, узагальнення науково-теоретичних і дослідних даних, систематизація тощо - з метою зіставлення різних точок зору, уточнення змісту окремих понять, сутності комунікативної готовності слідчого та встановлення вимог, яким він має відповідати.

Виклад основного матеріалу. Під час проведення бесіди слідчий має вміти не тільки налагодити психологічний контакт, але й розуміти налаштування допитуваного до процесу бесіди. Одним із важливих визначень цього $\epsilon$ розуміння невербальної мови, оскільки це надає можливості виявляти наявність бажання давати свідчення, діагностувати брехню тощо. Тому для спроможності використовувати та інтерпретувати невербальні засоби спілкування слідчому варто знати ряд жестів, поз, міміку, ходу, що свідчать про те чи інше ставлення особи до спілкування. Крім того, він має вміти ці знання використовувати та застосовувати в процесі бесіди з метою прогнозування ефективності допиту. 
Допит - це складна слідча дія, що зумовлена певними труднощами, з якими стикаються слідчі підрозділи органів Національної поліції, оскільки він пов'язаний із процесом встановлення психологічного контакту з учасниками кримінального провадження, за результатом проведення якого необхідно отримати важливу інформацію.

Психологічними особливостями проведення допиту $\epsilon$ чітка регламентація, невизначеність плину комунікативного процесу, конфліктність, необхідність високого ступеня концентрації слідчого на процесі допиту, необхідність ґрунтовної підготовки до проведення допиту, можливість зміни інформації, наявність недовіри до представників правоохоронних органів та небажання у зв'язку із цим давати правдиву інформацію, звертання уваги на обмовки та дрібниці, які можуть бути корисними для розслідування матеріалів кримінального провадження та ін.

Специфіка проведення допиту визначається залежно від особи, яку допитують, тобто допиту підозрюваного (ч. 2 ст. 95, ст. 133, п. 4 ст. 224 КПК України [1] та ін.), потерпілого (ч. 2 ст. 95, ст. 133 КПК України [1] та ін.), свідка (ст. 66 КПК України, ч. 3 ст. 95, ст. 96, ст. 133, п. 3 ст. 224 КПК України [1] та ін.), експерта (ст. 69, ч.2 ст. 95 КПК України та ін.), малолітньої або неповнолітньої особи (ст. 226 КПК України [1] та ін.). Залежно від цього слідчому необхідно будувати певну лінію комунікації.

Так, наприклад, у процесі допиту підозрюваного слідчому необхідно налаштовуватись на темп розмови, манери спілкування, способи приховування та викривлення інформації, також ураховувати хвилювання особи. У процесі допиту свідка слідчому необхідно визначити можливість сприймати факти, про які він дає показання, а також щодо інших обставин, які можуть мати значення для оцінки достовірності показань свідка (ч. 1 ст. 96 КПК України). Важливим аспектом при допиті малолітньої або неповнолітньої особи є врахування віку та схильність дитини до фантазувань й можливості невірного сприйняття інформації.

Комунікативна готовність до проведення доnumy детермінується уміннями слідчого:

використовувати засоби емоційного впливу, які спрямовані на спонукання допитуваного до каяття й чистосердечного зізнання;

використовувати в допиті фактор раптово-

сті, при постановці несподіваних питань;

справляти позитивне враження;

викладати свої думки грамотно, чітко, зро-

зуміло, доступно;
- виявляти гармонію спокою і впевненості, стриманість у словах і виразах;

володіти технікою комунікативної поведінки під час допиту;

- уникати під час допиту обговорення суперечливих питань особистісного інтимного характеру, що не стосуються кримінального провадження;

- шанобливо ставитись до об'єкта допиту;

допитувати в режимі відеоконференції з такими змінами зовнішності і голосу, за яких їі неможливо було б упізнати (ч. 10 ст. 232 КПК України [1]);

- проводити опитування особи у режимі відео- або телефонної конференції, яка через знаходження у віддаленому від місця проведення досудового розслідування місці, хворобу, зайнятість або з інших причин не може без зайвих труднощів вчасно прибути до слідчого, прокурора (ч. 11 ст. 232 КПК України [1]);

використовувати прийоми логічного впливу, які полягають у пред'явленні доказів, що спростовують показання об'єкта допиту або потребують їх деталізації та можуть призвести до протиріч між показаннями співучасників;

долати та нейтралізувати мотиви, що спонукають об'єкта допиту надавати неправдиві показання;

- встановлювати психологічний контакт під час допиту;

- долати бар'єри в спілкуванні, які можуть виникати під час допиту;

проводити одночасний допит двох чи більше вже допитаних осіб для з'ясування причин розбіжностей в їхніх показаннях (ч. 9 ст. 224 КПК України [1]);

- враховувати специфіку підліткового віку під час допиту малолітньої або неповнолітньої особи (ст. 226 КПК України [1]);

дотримуватися дистанції під час допиту;

використовувати метод переконання, спрямованого на мислення, відчуття і волю, шляхом приведення доводів і пред'явлення доказів, за яких у об'єкта допиту формується усвідомлене бажання надавати правдиві показання в умовах збереження свободи вибору його поведінки;

встановлювати таку атмосферу у процесі спілкування з об'єктом допиту, яка забезпечить готовність і бажання давати показання,

- слухати, чути та почути об'єкта допиту.

Відомий науковець, професор психології А. Мейерабіан [2] в галузі вербального та невербального спілкування встановив, що тільки на 7\% відбувається передача інформації вербальними засобами, на 55\% - невербальними, а також 
38\% - за рахунок звукових засобів (включаючи тон голосу, інтонацію звуку).

Тобто відмінність вербального спілкування від невербального полягає у тому, що перше, як правило, контролюється особою (винятком $\epsilon$ обмовки), а невербальне зумовлене імпульсами нашої підсвідомості і тому вірогідність підробити ці імпульси незначна. Тому у професійній діяльності слідчий має враховувати ці види спілкування і вміти координувати свої дії та учасників процесу. Відповідно, ми вважаємо, що найбільш важливою оцінкою результативності проведення допиту $\epsilon$ вміння слідчого визначати правдиву інформацію і відрізняти її від брехні.

Слідчий має вміти використовувати психологічні знання для визначення невербальних жестів, які можуть свідчити про неправдивість показань або небажання підозрюваного «відкриватись». Розглянемо деякі з них.

1. Найпоширенішим із таких жестів $\epsilon$ nрuкриття рукою рота та торкання до носу. У першому випадку цей жест зумовлений тим, що коли людина бреше, iї мозок посилає імпульс прикрити рот у спробі затримати слова обману. У другому випадку, дотик до носа $є$ витонченим, замаскованим. Він може виражатися в кількох легких дотиках до ямки під носом, або бути виражений одним швидким, майже непомітним дотиком.

Одне з пояснень природи цього жесту полягає в тому, що коли погані думки проникають у свідомість, підсвідомість велить руці прикрити рот, але в найостанніший момент, бажаючи замаскувати цей жест, рука легко торкається носу.

2. Дослідження, проведені Ніренбергом і Калеро [3] з вивчення жесту схрещених пальців рук, дали змогу стверджувати, що цей жест позначає розчарування і бажання людини приховати своє негативне ставлення. Цей жест має три варіанти: схрещені пальці рук підняті на рівні особи, руки лежать на столі, на колінах при сидячому положенні або внизу перед собою у стоячому положенні. Якщо під час допиту підозрюваний буде давати свідчення із зазначеними жестами, це може призвести до непорозуміння та небажання допитуваного взагалі давати свідчення. Тому для розслаблення слідчому вжити низку заходів, що дають змогу людині витягнути руки вперед і оголити долоні, інакше буде присутня ворожа нотка в процесі переговорів.

3. Викриттям неправдивих свідчень може бути потирання вік. Цей жест викликаний тим, що в мозку з' являється бажання сховатися від обману, підозри або брехні, з якими він стикається, або бажання уникнути погляду в очі людині, якій він говорить неправду.
4. Такі жести, як почухування шиї та поправлення комірця, можуть також свідчити про брехню. За дослідженнями Д. Морриса [4], коли особа говорить неправду, у неї виникає відчуття свербіння в ніжних м'язових тканинах шиї, і їй необхідно почухатись, для того щоб послабити ці відчуття. Схоже, це є прийнятним поясненням того, чому деякі люди відтягують комірець, коли вони брешуть і підозрюють, що їх обман розкритий. Також у того, хто бреше, виступають крапельки поту на шиї, коли він відчуває, що його запідозрили у брехні.

Уважним слідчому варто бути, коли підозрюваний схрестив руки, це універсальний жест, що означає оборонний або негативний стан людини. Слідчому варто знати, що до тих пір, поки людина триматиме руки схрещеними на грудях, вона зберігатиме негативне налаштування. Для того щоб допитуваний розімкнув руки, слідчому необхідно дати йому в руки ручку, книгу, папір, будь-який предмет, беручи який, він витягне руки вперед. Тим самим він прийме відкрите положення і його ставлення зміниться. Можна також попросити підозрюваного нахилитися вперед, щоб трохи краще розглянути яку-небудь річ, внаслідок чого він теж розімкне руки.

За словами видатного психолога А. Піза [5], проблема викриття брехні полягає в тому, що підсвідомість працює автоматично і не контролюється особою, тому мова рухів тіла видає особу. Ось чому відразу помітно, коли брешуть люди, що рідко говорять неправду, незалежно від того, наскільки переконливо вони це підносять. У той самий момент, коли вони починають брехати, їхн тіло починає подавати абсолютно протилежні сигнали, що свідчить про брехню. Під час обману підсвідомість викидає пучок нервової енергії, яка виявляється в жестах, протилежних тому, що сказала людина.

Фізіологічною основою особистості є тип вищої нервової діяльності людини, який відображає силу та динаміку нервових процесів у мозку. Специфікою психоемоційного стресу особи, до якої не завжди застосовуються закономірності процесу розвитку, є ступінь прояву ознак стресу. I це буде залежати від низки факторів та психічних станів (мотивація, установка, очікування). Якщо свідомість оцінує ситуацію як небезпечну, то відбувається емоційна оцінка події.

Медичні дослідження доводять, що в різних стресових ситуаціях організм реагує стереотипно, за одним і тим самим шаблоном, передусім сигнал роздратування надходять до мозкового центру, підсилюючи при цьому гормональну актив- 
ність, а також активність вегетативно-нервової системи. Відбувається рефлекторна активація кори наднирників і надходження у кров адреналіну та норадреналіну. Тому змінами в реакціях поведінки проявляються психосоматичні розлади (напруження м'яз лиця, тремтіння верхніх кінцівок, зміна ритму дихання).

Таким чином, в людини, яка налякана або підсвідомо хоче ввести в оману, додатково мимоволі виділяються адреналін та кортизол, підвищується серцевий ритм та частішає дихання, тобто людина входить у стан підвищеної симпатичної активності.

«Адреналин» - це гормон та медіатор речовини надниркових залоз, що входять до групи фізіологічно активних речовин (адреналін також утворюється у процесі збудження вегетативної нервової системи) [6].

«Кортизол» - природний глюкокортикоїдний гормон, що виробляється корою наднирників. Кортизол синтезується організмом із холестерину, що надходить в організм у складі ліпопротеїдів низької щільності або синтезується в клітинах з ацетил-коензиму А [6].

$€$ кілька типів стресових реакцій, i кожному з них притаманний свій біологічний профіль. Знання фізіологічного адаптаційного напруження $\epsilon$ ефективними у професії слідчого, тому що сприяють більш якісному досудовому розслідуванню.

Для того, щоб продіагностувати по невербальних жестах наявність брехні, необхідно стежити за жестами усього тіла особи. Ось чому під час допиту підозрюваного необхідно саджати на стілець у місці, яке добре проглядається або освітлене, щоб його було видно і легше було б виявити, коли він говорить неправду. Зрозуміло, що брехня буде менш помітна, якщо особа в цей момент сидітимете за столом і тіло буде часткове приховане.

Висновки. Таким чином, знання мови рухів тіла допоможуть слідчому виявляти, говорить допитуваний правду чи навпаки. Але варто зазначити, що у процесі оцінки результатів спілкування та визначення правдивості слідчому треба застосовувати не окремі прийоми вивчення вербального та невербального спілкування, а тільки у сукупності. Оскільки, наприклад, розкриті долоні асоціюються з чесністю, але, якщо особа, що обманює, посміхається, одночасно кажучи брехню, мікросигнали ї̈ організму видадуть потайні думки. Це можуть бути звужені зіниці, підняті брови або викривлення куточка рота, і всі ці сигнали є протилежними широкій усмішці.

Важливим $\epsilon$ врахування фізіологічного та медичного аспектів під час спілкування слід- чого з підозрюваним. Оскільки мозок знає правду і вербально може сказати недостовірну інформацію, невербальне тіло видає себе у зв'язку з фізіологічними процесами, які відбуваються в організмі на фоні дії гормонів адреналіну та кортизолу.

Процес оцінки допиту у всіх випадках поєднується з елементами прогнозування подальшої діяльності слідчого, де використання результатів проведеного допиту поєднується з розробкою заходів, що не допускають повторення виявлених у процесі аналізу помилок. Тактично грамотний аналіз результатів допиту дає змогу встановити достатність отриманої інформації, оцінити ії правдивість і достовірність, прогнозувати поведінку допитуваного на подальших етапах спілкування.

Перспективи подальших розвідок у цьому напрямі зумовлені подальшою необхідністю поєднання юридичного, психологічного та медичного аспектів дослідження правдивості показань та аудіовізуальної психодіагностики брехні.

\section{Література}

1. Кримінальний процесуальний кодекс України : Кодекс України від 13.04.2012 р. № 4651-VI. URL: https://zakon.rada.gov.ua/laws/card/4651-17/ sp:head. (дата звернення: 03.05.2020).

2. Mehrabian, Albert. Silent Messages: Implicit Communication of Emotions and Attitudes (англ.). 2nd. Belmont, CA: Wadsworth, 1981.

3. Ниренберг Дж., Калеро Г. Прочти человека как открытую книгу. Издательство: Попурри, 2008. 272 c.

4. Десмонда Морриса. Наблюдая за человеком. Фундаментальное исследование всех невербальніх сигналов. Попурри, 2017. 315 с.

5. Алан Аиз Язык телодвижений (перевод с английского). Москва : Изд-во ЭКСМО-Прес, 2002. 272 c.

6. Адреналін, кортизол [визначення термінів]. URL: https://ru.wikipedia.org/wiki/. (дата звернення: 10.10.2020).

Пасько О. М., кандидат юридичних наук, доцент, доцент кафедри криміналістики та психології Одеського державного університету внутрішніх справ https://orcid.org/0000-0001-9555-1101

Нікітенко Р. П., кандидат медичних наук, доцент, доцент кафедри хірургії № 1

Одеського національного медичного університету https://orcid.org/0000-0003-4214-5534

ПІВАЕННОУКРӒ̈НСБКИЙ ПРАВНИЧИЙ ЧАСОПИС 